\title{
Seroprevalence of Human Cytomegalovirus Infection among HIV Patients in Khartoum State
}

\section{Mahjoob MO*, Ahmed AA, Omer FH, Ali MF, Ali SE, Ali MA, Mohammed SI and Elawad HE \\ Department of Microbiology, Medical Laboratories Sciences, Omdurman Islamic University, Sudan}

*Corresponding author: Mahjoob Osman Mahjoob, Omdurman Islamic University, Omdurman, Sudan, Faculty of Medical Laboratory Sciences Omdurman, Sudan, Tel: +249914449443; Email: Mahjoob212@hotmail.com

\section{Abstract}

Background: Human Cytomegalovirus (HCMV) is one of the opportunistic infections associated with significantly high morbidity and mortality among patients living with immunodeficiency syndrome. CMV has been reported to enhance HIV replication and accelerate the progression of HIV infection to AIDS.

Aim: The aim of this study was to determine the prevalence of HCMV among HIV patients in Khartoum State, Sudan, during the period April to July 2018.

Methods: The study was carried out in Khartoum State, Sudan. A total of 92 HIV sero-positive cases were included. HCMV IgG and IgM antibodies were detected using Enzyme Linked Immune Sorbent Assay.

Results: Among 92 HIV positive samples, 91 (99\%) were found positive for HCMV- IgG while 3 samples (3.2\%) were positive for HCMV- IgM.

Conclusion: In Sudan, the existence of HCMV in patients with HIV infection was confirmed by using ELISA. These findings indicate that CMV is hyper-endemic in HIV seropositive patients in Khartoum, Sudan.

Keywords: HIV; HCMV; ELISA; Sudan

\section{Introduction}

Human Cytomegalovirus (HCMV) is a large encapsulated double stranded DNA virus. It belongs to the beta - herpes virus group. Most likely it is one of the most common latent infections known to humans $[1,2]$.

HCMV infection is defined as isolation of the HCMV virus or detection of viral proteins or nucleic acid in any body fluid or Tissue specimen (e.g., plasma, serum, whole blood, peripheral blood leucocytes, CSF, urine, or tissue) [3].

Normally it is controlled by the cellular Immune response and hence characterized as a self-limiting infection in healthy individuals. In contrast, the HCMV in Immunosuppressed individuals as in case of HIV infection carries a risk of high morbidity and mortality [4]. Clinical 


\section{Open Access Journal of Microbiology \& Biotechnology}

disease due to HCMV has been observed in up to $40 \%$ of the patients with advanced HIV disease [5].

In HIV infected individuals, opportunistic viral infections are one of the major cause of morbidity and mortality. These agents cause infections which could be asymptomatic or mildly symptomatic in immunocompetent individuals, and it is often selflimiting. However, in immunosuppressed individuals and individuals with malignancy, infection with these agents leads to severe life-threatening diseases $[6,7]$.

The ELISA is the most common test available for measuring CMV IgG (past exposure to CMV) and CMV IgM (recent or reactivation of CMV infection) [8]. CMV infection among HIV patients has been reported in Sudan [9]. But still the surveillance of CMV infection in immunocompromised cases needs to be investigated to meet the future health challenges.

Cytomegalovirus is a ubiquitous and infection caused by this virus has become endemic throughout the world, with prevalence ranging from $40-100 \%$ [10].

\section{Materials and Methods}

\section{Study Design}

This was a cross sectional study that was carried out in Khartoum state, Sudan, during period from April to July 2018.

\section{Study Population}

The study population constituted of 92 HIV seropositive patients both males and females. The age group was between 20 to $>50$ years.

\section{Data Collection}

The data was collected through personal interview using structured questionnaire to provide information regarding age, sex, residence, educational level and treatment.

\section{Clinical Samples}

A $5 \mathrm{ml}$ of whole blood was collected from each HIV infected patient by vein puncture. Serum was separated after centrifugation of blood at $3000 \mathrm{rpm}$ for 5 minutes and then stored at $-20^{\circ} \mathrm{c}$. All the sera were later analyzed by using ELISA.

\section{Serology}

Commercial ELISA kits were used to detect HCMV IgG (fortress diagnostics) and IgM (Chemux BioScience, INC) according to the procedure described by the manufacturer.

\section{Principle of the Test}

Purified CMV antigen is coated on the surface of microwells. Diluted patient serum was added to the wells and the CMV specific antibody, if present binds to the antigen. All unbound materials are washed away. Excess enzyme conjugate was washed off and Tetramethylbenzidine (TMB) chromogenic substrate was added. The enzyme conjugate catalytic reaction was stopped after a specific time. The intensity of the color generated is proportional to the amount of specific antibody in the sample. The results are read by a microwell reader and compared in a parallel manner with calibrator and controls.

\section{Assay Procedure}

The desired number of CMV-antigen coated strips of microtitre wells were placed into the holder and 1:40 dilution of each negative control, positive control and calibrator was prepared by adding $200 \mu \mathrm{l}$ of sample diluents to $5 \mu \mathrm{l}$ of each of the reagents and mixed properly. One hundred $\mu \mathrm{l}$ of the diluted sera, calibrator and controls were dispensed into appropriate wells. For the reagent blank, $100 \mu \mathrm{l}$ sample diluents were dispensed into the well in position A1. The holder was tapped gently to remove air bubbles from the liquid and also to mix the contents of each well. The test strips were incubated for 30 minutes at room temperature. After incubation, the liquid content was removed and further dapped onto tissue paper pad. During each wash, $100 \mu \mathrm{l}$ of washing buffer was dispensed into the test wells and poured off. After the third wash, $100 \mu \mathrm{l}$ of TMB chromogenic substrate was dispensed into each well and incubated again for 30 minutes at room temperature after which $100 \mu \mathrm{l}$ of stop solution was added to stop the reaction. A microwell reader was used to read the optical density at $450 \mathrm{~nm}$.

\section{Interpretation of the Results}

This was carried out according to the manufacturer's recommendations.

Negative result: CMV index of less than 0.90 for $\operatorname{IgM}$ and IgG antibodies. 


\section{Open Access Journal of Microbiology \& Biotechnology}

Equivocal result: CMV index between 0.91-0.99 for IgM and IgG antibodies, and the sample should be retested.

Positive result: CMV index of 1.0 or greater for IgM and IgG antibodies.

\section{Statistical Analysis}

Data obtained from the study were analyzed by ChiSquare using software Statistical Package for Social Science (SPSS version 16) to determine the association between prevalence of infection and the studied parameters. Values obtained were considered statistically not significant ( $\mathrm{P}$ value $>0.05$ ).

\section{Ethical Consideration}

A written consent was obtained from participants after carefully explaining the concept of the study to them. Ethical clearance was sought and obtained from the University of Khartoum, Khartoum, Sudan.

\section{Results}

Out of 92 cases, IgG antibodies against CMV were detected more than IgM antibodies. The results of ELISA IgG and IgM for the diagnosis of HCMV in serum samples collected from HIV patients in Khartoum state are shown in Table 1.

\begin{tabular}{|c|c|c|c|}
\hline Test & Positive & Negative & Total tested \\
\hline CMV IgG & $91(99 \%)$ & $1(1 \%)$ & 92 \\
\hline CMV IgM & $3(3.3 \%)$ & $89(96.7 \%)$ & 92 \\
\hline
\end{tabular}

Table 1: Frequency of CMV IgG and IgM antibodies in HIV seropositive patients in Khartoum State.

We found that CMV IgG positive result was higher in age between 30-50 years ( 71 out of 91 positive patients), 12 patients less than 30 years old, while only 8 positive patients above 50 years. IgM was equal in each age group as shown in Table 2.

\begin{tabular}{|c|c|c|}
\hline Age group & CMV IgG (Positive) & CMV IgM (Positive) \\
\hline$<30$ & 12 & 1 \\
\hline $30-50$ & 71 & 1 \\
\hline$>50$ & 8 & 1 \\
\hline Total No. $(\%)$ & $91(99 \%)$ & $3(3.2 \%)$ \\
\hline P value & $\mathbf{0 . 1}$ & $\mathbf{0 . 6 5 2}$ \\
\hline
\end{tabular}

Table 2: Seroprevelance of CMV among HIV infected patients regarding their age.
49 males and 42 females were positive for CMV IgG. Two males and only one female were shown positive result for CMV IgM as seen in Table 3.

\begin{tabular}{|c|c|c|c|c|}
\hline Test & Male & Female & Total. No (\%) & P value \\
\hline CMV IgG (Positive) & 49 & 42 & $91(99 \%)$ & $\mathbf{0 . 6 1 5}$ \\
\hline CMV IgM (Positive) & 2 & 1 & $3(3.2 \%)$ & $\mathbf{0 . 3 8 5}$ \\
\hline
\end{tabular}

Table 3: Seroprevalence of CMV among HIV infected patients regarding their gender.

\section{Discussion}

Susceptibility of HIV seropositive individuals to CMV positive is a controversial issue [11-13]. The result of investigations from endemic parts of the world showed higher CMV seroprevalence rates in HIV-infected individuals. This study was designed to determine the seroprevalence of CMV antibodies in HIV infected patients in Khartoum state.

In this study, the seroprevalence of CMV IgG was 99\% among our HIV-infected patients. This is in agreement with report from the Khartoum state, south west Nigeria and Burkina Faso by Khalid A Enan et al. [9] at and Ledru, et al. [14] respectively that documented a prevalence of anti-CMV IgG antibody of $100 \%$ among HIV-infected patients. The high CMV IgG seropositivity rate in this study is suggestive of widespread past exposure to infection.

However, lower prevalence rates have also been reported in other countries like India (10.4\%) [15] and 95.6\% among HIV positive Malawian children [16]. These differences in prevalence maybe related to characteristic of the study population and the sensitivity of the screening tests.

Results of one study reports CMV IgM antibody seroprevalence to be $8.4 \%-9 \%$ among HIV-infected Thai children [17]. Whereas higher than our study (3.2\%) and other recorded in USA (2.3\%) [17]. The variation in in seroprevalence of CMV IgM observed may probably be due to epidemiological and methodological differences. There was no children in our study, the smallest age was 20 years old.

There is need to further investigate the prevalence of CMV infection immuno-compromised cases in other part of the country to have a better picture of the extent of this problem in Sudanese scenario. 


\section{Open Access Journal of Microbiology \& Biotechnology}

\section{Conclusions and Recommendations}

Our findings show high seroprevalence of CMV IgG and low seroprevalence of IgM among the study group. This study reveals the need for further investigations in different parts of the country to highlight the severity of the problem. This will help in better management of the HIV cases by early diagnosis of CMV antibodies in the patients.

\section{References}

1. Chakravarti A (2009) Cytomegalovirus infection: An Indian perspective. Journal of Clinical and Diagnostic Research 27(1): 3-11.

2. John S, Sissons P (2006) Latency and reactivation of human cytomegalovirus. J Gen Virol 87(7): 17631779.

3. Ljungman P, Griffiths P, Paya C (2002) Definitions of cytomegalovirus infection and disease in transplant recipients. Clin Infect Dis 34(8): 1094-1097.

4. Springer KL, Weinberg A (2004) Cytomegalovirus infection in the era of HAART: a fewer reactivations and more immunity. J Antimicrob Chemother 54(3): 582-586.

5. Kirubakaran SI (2004) Cytomegalovirus infection in HIV-infected patients- a review. Clinical Microbiology Newsletter 26(18): 137-144.

6. Xu LP, Zhang HY, Huang XJ, Liu KY, Liu DH, et al. (2007) Hemorrhagic cystitis following hematopoietic stem cell transplantation: Incidence, risk factors and association with CMV reactivation and graft-versushost disease. Chin Med J 120(19): 1666-1671.

7. Musacchio JG, Carvalho Mda G, Morais JC, Silva NH, Scheliga A, et al. (2006) Detection of free circulating Epstein-Barr virus DNA in plasma of patients with Hodgkin's disease. Sao Paulo Med J 124(3): 154-157.

8. Hogg RS, Yip B, Chan KJ, Wood E, Craib KJ, et al. (2001) Rates of disease progression by baseline CD4 cell count and viral load after initiating triple drug therapy. JAMA 286(20): 2568-2577.

9. Mohammed OS, Hussein ARME, Elkhidir IM, Enan KA (2017) Prevalence and Molecular Detection of Human
Cytomegalovirus among HIV Patients in Khartoum State, Sudan. EC Microbiology 7(1): 21-25.

10. Notomi T, Okayama $\mathrm{H}$, Masubuchi $\mathrm{H}$, Yonekawa $\mathrm{T}$, Watanabe K, et al. (2000) Loop-mediated isothermal amplification of DNA. Nucleic Acids Res 28(12): 63.

11. Ryota Suzuki, Tetsushi Y, Ihira M, Enomoto Y, Shoji I, et al. (2006) Development of the loop-mediated isothermal amplification method for rapid detection of cytomegalovirus DNA. Journal of Virological Methods 132(1-2): 216-222.

12. Sachithanandham J, Ramamurthy M, Kannangai R, Daniel HD, Abraham OC, et al. (2009) Detection of opportunistic DNA viral infections by multiplex PCR among HIV infected individuals receiving care at a tertiary care hospital in South India. Indian J Med Microbiol 27(3): 210-216.

13. Leach CT, Cherry JD, English PA, Hennessey K, Giorgi JV, et al. (1993) The relationship between T-cell levels and CMV infection in asymptomatic HIV-1 antibodypositive homosexual men. J Acquir Immune Defic Syndr 6(4): 407-413.

14. Ledru E, Diagbouga S, Ledru S, Cauchoix B, Yameogo $M$, et al. (1995) A study of Toxoplasma and Cytomegalovirus Serology in Tuberculosis and in HIVInfected Patients in Burkina Faso. Acta Trop 59(2): 149-154.

15. Lanjewar DN (2011) The Spectrum of Clinical and Pathological Manifestations of AIDS in a Consecutive Series of 236 Autopsied Cases in Mumbai, India. Pathology Research International: 12.

16. Rosauro V, Buck WC, Kazembe PN, Phiri S, Andrianarimanana D, et al. (2016) Seroprevalence of CMV, HSV2 and HBV among HIV-infected Malawian Children: cross sectional survey. J Trop Pediatr 62(3): 220-226.

17. Schoenfisch AL, Dollard SC, Amin M, Gardner LI, Klein RS, et al. (2011) Cytomegalovirus shedding is highly correlated with markers of immunosuppression in CMV-seropositive women. J Med Microbiol 60(6): 768-774. 